\title{
Emic Analysis Towards Penghayat Kepercayaan Dynamics in the Democratic Era
}

\author{
Gayes Mahestu ${ }^{1 *}$
}

${ }^{1}$ Department of Communication, Bina Nusantara University, Jalan Kebon Jeruk Raya No.27, Jakarta 11530

\begin{abstract}
This paper tries to examine the qualitative reality about current of belief' "Penghayat Kepercayaan" dynamics in the Democratic Era. Penghayat Kepercayaan is a name for non-religious society or some people called as Agama Asli Nusantara. Becoming Penghayat will face some special challenges since the society generally has negative stereotype towards them. The research method used was qualitative by using emic approach. The subject of this research was Penghayat Kepercayaan (the believers) who was covered by Majelis Luhur Kepercayaan Terhadap Tuhan YME Indonesia (MLKI). The informants were determined by using purposive sampling technique. The research finding was the democratic country generally considered the diversity and all citizens have the similar rights and obligations, however, until now, Penghayat Kepercayaan is struggling to get the acceptance especially for their identities. The new problem about the existence of Penghayat Kepercayaan in the social interaction will evoke their feelings of useless in actualizing their life and their occupations. The perspective towards the democracy of Pancasila by some Penghayat Kepercayaan did not represent enough their existence as the diversity in Indonesia, while for others, this current democracy had already fulfilled their needs.
\end{abstract}

Keywords: Agama Asli Nusantara; Democracy; Emic; Penghayat Kepercayaan Indonesia, Religion

\section{Introduction}

Indonesia is a multicultural country. It consists of a thousand ethnic groups, customs, languages, religion, belief and etc. As we know in Indonesia there are six formal religions such as Islam, Protestantism, Catholicism, Hinduism, Buddhism, and Confucianism but beside that there is also nonreligion belief which is call Agama Asli Nusantara, Noble Religion, Traditional Religion, and they call them self as "Penghayat Kepercayaan". Talking about believing in God Almighty is quite interesting to be discussed according to Andri Hernandi the general chief of Aliran Kebatinan Perjalanan that there are a lot of viewpoints in the society that Penghayat Kepercayaan is outsider community; because they consider that they have some activities which are unusual in the society based on the certain value [1]. Penghayat Kepercayaan is not a religion, but a belief in God Almighty existence which is actualized by doing things consciously to achieve physical and spiritual goals. The basic of a belief in God Almighty

existence is every condition and situation which is witnessed and known spiritually [2].

Most people in this country, including Penghayat Kepercayaan who believes in God Almighty, were familiar with sajen/sasajen, traditional ceremonies and rituals. This event had different form, procedure and integrity which was unique and specific based on the culture and custom in a certain area. The total of them could be thousands because each village in this country had their own tradition [3]. Nevertheless, some people interpret the spirituality as witchcraft, kanuragan, shamanism, klenik and etc. So, this causes any negative stereotype in society towards Penghayat Kepercayaan that this group do any kind of

*Corresponding author: gayesmahestu@binus.ac.id 
activities such as shamanism, heresy and deviating the religion and Pancasila.

Religion and kebatinan (spirituality/belief) have similar elements that are one Panembah (worship to God Almighty) and nobility. The only different thing is on the emphasis and pressure given. For religion, the emphasis is given to Panembah, while kebatinan gives the pressure towards the accomplishment for nobility and completeness of life [4]. Relevant to what have been stated on UNESCO declaration about diversity in Paris on November $2^{\text {nd }} 2011$ that the Declaration delineates cultural diversity as a factor in development. "Cultural diversity widens the range of options open to everyone; it is one of the roots of development, understood not simply in terms of economic growth, but also as a mean to achieve a more satisfactory intellectual, emotional, moral and spiritual existence [5].

Recently, discussion about Law number 23, year 2006 on Demography Administration in Article 61 Paragraph 2 and Article 64 Paragraph 2 [6]. It is stated that the action of emptying the religion information on Family Identity Card and Identity Card is intended for Penghayat Kepercayaan who believes in God Almighty, but they will still get the service in the process of administering the identity and they will still be registered in the demographic database. Without hesitating, this process of registering often causes a problem related to the existence of Penghayat Kepercayaan in the society and it engenders the feelings of useless of Penghayat to actualize their life and their occupation. Certainly, if this keeps going on, there will be high social inequity which gives great implication towards the life of the people and of the nation.

\section{Methodology}

This paper using qualitative method along with emic approach. Emic is a kind of research approach which often used in ethnography. Emic means the exploration and the explanation of reality based on person's/group's internal viewpoint from certain ethnic. As mention that where little empirical research has been done, emic research is critical. We need to know how people in under-researched places view the constructs of interest; otherwise, researchers impose a particular view, developed elsewhere [7]. Some emic measures were developed to study specific cultural personality constructs. However, few multidimensional personality measures have been developed to cover the wide spectrum of personality constructs within the local cultural contexts. Many of the early attempts to develop multidimensional personality measures adapted and modified imported Western measures to accommodate the emic constructs in Cheung [8].

In Indonesia there is about 250 groups of Penghayat Kepercyaan such as Buhun, Aliran Kebatinan Perjalanan, Parmalim, Kejawen, Budi Daya, Wetu Telu, Kaharingan, Sunda Wiwitan, etc. This research was using informants from MLKI members who were determined by using purposive sampling. MLKI or Majelis Luhur Kepercayaan Terhadap Tuhan Yang Maha Esa Indonesia itself is an only institution for Penghayat Kepercayaan who believes in God Almighty and community of Kepercayaan Adat in Indonesia. Which is legitimate on October $13^{\text {th }} 2014$ [9].

\section{Discussion}

Small survey researcher did in June 2017 to 147 respondent (age 18 - 30 year $79 \%$ and $31-45$ year $21 \%$ ). First question respondent ask to "give a first word they thinking after saw picture group of Men wear black Sundanese traditional costume with sesajen in front of them". The result show 31.2\% respondent say Dukun (shaman); 21\% Budayal acara daerah (cultural ceremony); $15.1 \%$ aliran sesat (deviant sect); $10.8 \%$ ilmu gaib/ kanuragan (witchcraft); 9\% Sesajen; Penghayat Kepercayaan $7.9 \%$; etc $5 \%$. Second question asked to respondent is "have you ever heard Penghayat Kepercayaan Terhadap Tuhan Yang Maha Esa?" the result show 61\% "No, don't know"; 39\% "Yes, I know".From that small survey we know that there still a misperception to Penghayat Kepercayaan, although they already heard about them.

Actually, the existence of Penghayat Kepercayaan has already warranted by: the 1945 Constitution Article 28E Paragraph 2 on Human Rights which stated: "Every person has right to be freedom in believing a belief, expressing ideas and attitudes based on their conscience"; Article 29 Paragraph 2 on Religion which stated that "the government warrants the freedom for each resident to choose their religion and their beliefs"; and Article 32 Paragraph 1 on Education and Culture which said: "The government promotes the national culture of Indonesia in the rise of world civilization by warranting the freedom of the citizens in sustaining and promoting the cultural value" 10 . The presence of this case should become the evidence that the existence of Penghayat Kepercayaan had actually 
had similar rights which had been regulated by the Law.

Democratic does not mean showing the diversity which can evoke the anarchy. However, the decision was taken from discussion to get the agreement, so the main truth was not underlain on the quantity of votes, but it was on the agreement made toward substantial idea. As stated above, the indicator of success for the religious development in Indonesia was on two things, they are: the upgrading of knowledge, Penghayatan, service, and the implementation of religious ideology, and the increasing the harmony among people with religion $^{11}$.

The existence of Law Number 23, Year 2006 on Demography and Administration, they struggle to get judicial right related to the belief recognition on Identity Card and Family Identity Card actually had been discussed for a long time ago, but there had no certain agreement that could accommodate the needs of Penghayat Kepercayaan. As revealed by Prof. Dr. Maria Faria Indrati, a professor in University of Indonesia and also a constitutional judge, in reality those kinds of belief were existed before the religion came, so we should admit that the reality was existed and they Penghayat Kepercayaan were existed. Since there was no information about their 'religion' on their ID card/Family Identity Card, they will be considered as 'people without religion'12. Recently in November $7^{\text {th }}$ 2017, The Constitutional Court (MK) granted judicial review for Law Number 23, Year 2006 and decide "the state must guarantee that every believer can access the religious column in the Identity Card". It is a good news for Penghayat Kepercayaan more than access to write "kepercayaan" in their identity card and exert the belief on the registration legally but furthermore it bring new journey to claim their existence in Indonesian democracy.

Engkus Ruswana, a general chief of Penghayat Budi Daya, stated that external challenge came from the government and the legislature did not have a strong commitment to empower 'Penghayat', so it seemed that they were just warranted for their existence but they must not be bigger/developed. It was proven by seeing how small the state budget for the development and the establishment of Penghayat Kepercayaan. Frequently, the reorganization of nomenclature or the affiliation of directorate of Kepercayaan and other directorates happens. There was still social isolation towards Penghayat Kepercayaan by the society because of lacking of their knowledge/information about the existence of Penghayat Kepercayaan and they were always considered as non-religious or atheist group which did not belief in $\mathrm{God}^{13}$. Racial differences can potentially affect economic inequalities within countries by mechanisms that are different from the actions of ethnic or cultural differences ${ }^{14}$.

In fact, either in theology or sociology, religion or belief could be seen as an instrument to understand a life in this world ${ }^{15}$. Nonetheless, the obstacle of the existence of Penghayat Kepercayaan was not only occurred externally but also internally that was related to human resources as insufficient of managerial skill of Penghayat; simple life style of Penghayat, the lack of creativity of Pengahayat in demonstrating innovative cultural works; the degree of education and socio-economic which was still low; limited financial; lack of actualization; inadequacy and inability of socializing the ideology and organization.

Another fact which became the discussion was after their belief was agreed to be put in their ID card or Family Identity Card based on their own belief, had they been ready enough to expose their identities as Penghayat? Because it had been found that the majority of Penghayat Kepercayaan, actually, did not brave enough to show their identity as Penghayat and they preferred to admit themselves as the believer of other religions. In line with the findings said that some of the penghayat have a tendency to closed, worried and concerned about others opinions so they afraid to tell that they are Penghayat Kepercayaan ${ }^{16}$. It could be seen from one of the historical factor that there was a pressure towards Penghayat Kepercayaan in the society. The problem of this mistaken view towards Penghayat Kepercayaan was still happening because they cannot clarify and verify the wrong view spread in the society. Most of Penghayat was still introvert/afraid of being known as Penghayat as an impact of negative perspective made by the society, long marginalization and character assassination towards the belief in God Almighty. Penghayat Kepercayaan, sect that struggles to be the custodian of local wisdom, was still considered as a community and it is contradict to religion.

Basically, local wisdom is one of products of culture. As a cultural product, local wisdom existed because the need of value, norm, and regulation as a model for doing an action. Besides, local wisdom is one of knowledge for the society (culturally) existed in tradition and history, formal dan informal education, art, religion and other creative interpretations. Cultural discourse allows any kind of idea sharing and the interpretation continuously 
which result in the availability of some references for communication and self identity. When the modernization and globalization penetrate all part of this world, the references in form of value, symbols, and ideas are reassessed. There was a stabil institution, even nothing changes, that was forming and was formed by social process in Mufid, $2010^{17}$.

\section{Conclusion}

There was dualism view from Penghayat that was some people thought that Indonesia is not a democratic country yet because there is still discrimination in some aspects which finally it evokes an isolation in the society. Some of them thought that the democracy system in Indonesia has given a place for Penghayat Kepercayaan to receive their rights.

Diversity literacy needed to create harmonization, it will create abilities and commitments necessary to find, understand, assess, and act on information about the diversity of our Country, with harmonization will support the diversity and avoid catastrophe. Suppose that this research needs further analysis with bigger scale in order to illustrate the problem better and the solution to solve the problems.

\section{References and Notes}

1. A. Hernandi, "Eksistensi, Organisasi, Dan Kehidupan Penghayat Kepercayaan Terhadap Tuhan Yang Maha Esa", Balai Pelestarian Nilai Budaya Bandung Direktorat Jenderal Nilai Budaya, Seni, dan Film Kementrian Pendidikan dan Kebudayaan (2014).

2. A. Hernandi, "Upaya Revitalisasi Nilai Ajaran Kepercayaan Terhadap Tuhan Yang Maha Esa", Gelar Budaya Direktorat Jenderal Nilai Budaya, Seni dan Film, Departemen Kebudayaan dan Pariwisata (2007).

3. W. Giri, "Sajen Dan Ritual Orang Jawa Volume 1", Narasi, Jakarta (2002).

4. I. Harahap, "Rasionalisasi Religius dalam Diskursus Keagamaan di Indonesia: Kasus Parmalim Batak Toba", Antropologi Indonesia 0(61). Retrieved October 12, 2017, from http://journal.ui.ac.id (2014).
5. UNESCO, "Universal Declaration On Cultural Diversity", Paris, Retrieved from Http://Portal.Unesco.Org on October 5, 2017 (2001).

6. Undang Undang No. 23 Tahun 2006 Tentang Administrasi Kependudukan.

7. B. J. F. Punnett et. al., "The Emic-Etic-Emic Research Circle", AIB Insights vol. 17(1), Michigan University (2017).

8. F. M. Cheung, et. al., "Toward A New Approach To The Study Of Personality In Culture", American Psychologist, United States (2011).

9. MLKI, "Sejarah MLKI", Retrieved from http://www.mlki.or.id on October 18, 2017 (2017).

10. Undang Undang Dasar 1945.

11. R. M. Lubis, "Kebijakan Pembangunan Agama Di Indonesia Dalam Lintasan Sejarah", Harmoni Jurnal Multikultural \& Multireligius vol. 9(34), April-Juni, Puslitbang Kehidupan Keagamaan Badan Litbang \& Diklat Kementerian Agama RI, Jakarta (2010).

12. Detik.com, "Hakim Konstitusi: Aliran Kepercayaan Ada Sebelum Agama Datang", Retrieved from https://news.detik.com on 7 October 2017 (2017).

13. E. Ruswana, "Eksistensi, Organisasi, dan Kehidupan Penghayat Kepercayaan terhadap Tuhan Yang Maha Esa", Balai Pelestarian Nilai Budaya Direktorat Jenderal Nilai Budaya, Seni, dan Film Kementerian Pendidikan dan Kebudayaan RI, Bandung (2014).

14. G. Meisenberg, "Does Multiculturalism Promote Income Inequality?", Mankind Quarterly vol. 47(4) pp 3-39, Retrieved from https://search.proquest.com on October 12, 2017 (2007).

15. K. Hakiki, "Politik Identitas Agama Lokal (Studi Kasus Aliran Kebatinan)", Analisis: Jurnal Studi Keislaman vol. 11(1) pp 159-174 (2017).

16. G. Mahestu, "Thesis Dunia Intersubjektif Warga Penghayat Aliran Kebatinan Perjalanan", Universitas Padjajaran, Bandung (2012).

17. M. A. Syafi'i. Kebijakan Pembangunan Agama Di Indonesia Dalam Lintasan Sejarah. Harmoni Jurnal Multikultural \& Multireligius 2010 Volume Ix, Nomor 34, April-Juni. Jakarta : Puslitbang Kehidupan Keagamaan Badan Litbang \& Diklat Kementerian Agama RI (2010) 